\title{
A morphometric evaluation of human keratinized mucosa - statistical study
}

\author{
Evaluare morfometrică a mucoasei cheratinizate umane - studiu statistic
}
Simona Andreea Moraru1, Vanda Roxana Nimigean', Daniela Gabriela Bălan², Victor Nimigean ${ }^{3}$

\author{
${ }^{1}$ Disciplina Reabilitare Orală, Facultatea de Medicină Dentară, \\ Universitatea de Medicină şi Farmacie „Carol Davila“, Bucureşti, România \\ ${ }^{2}$ Disciplina Fiziologie, Facultatea de Medicină Dentară, \\ Universitatea de Medicină şi Farmacie „Carol Davila“, Bucureşti, România \\ ${ }^{3}$ Disciplina Anatomie, Facultatea de Medicină Dentară, \\ Universitatea de Medicină şi Farmacie „Carol Davila“, Bucureşti, România
}

\begin{abstract}
This study presents statistically processed morphometric data on maxillary and mandibular keratinised mucosa height and some clinical considerations. Measurements were performed at incisive, premolar and molar levels, in the maxillary and the mandibular jaws, in 31 patients (21 women and 10 men). The results obtained were centralised and the mean values of the keratinised mucosa height were determined, which were graphically presented. These results were then discussed by comparing with the findings in other studies.
\end{abstract}

Keywords: keratinized mucosa, morphometric evaluation, implant dentistry

\section{REZUMAT}

Acest studiu prezintă date de morfometrie privind înălţimea mucoasei cheratinizate maxilo-mandibulare determinate statistic şi câteva consideraţii clinice. Măsurătorile s-au făcut la nivel incisiv, premolar şi molar la maxilar şi mandibulă, pe 31 pacienţi, 21 femei şi 10 bărbaţi. Rezultatele obţinute au fost centralizate şi au fost determinate valorile medii pentru înălţimea mucoasei cheratinizate, rezultate care au fost prezentate grafic. Aceste rezultate au fost apoi discutate comparativ cu cele prezentate în alte studii.

Cuvinte cheie: mucoasă cheratinizată, evaluare morfometrică, implantologie orală

\section{INTRODUCERE}

Ţesuturile moi realizează la interfaţa cu implantul dentar sau cu suprastructura sa o sigilare biologică, o sigilare permucozală. O evaluarea morfometrică corectă a ţesuturilor moi periimplantare ar putea fi benefică pentru creşterea succesului clinic pe termen lung în implantologia orală (1).

Această sigilare din jurul implanturilor dentare creează o barieră fiziologică, protejând interfaţa implant-os de insultele produse de placa bacteriană şi de procedurile de menţinere a igienei orale (2).
Structura şi morfologia mucoasei orale cheratinizate reflectă o varietate de adaptări funcţionale, adaptările majore fiind rezultatul modificărilor evolutive ale speciei umane care au avut loc într-o perioadă lungă de timp $(1,3)$.

Morfologia mucoasei orale cheratinizate variază şi în funcţie de alinierea dinţilor, de suprafeţele de contact interdentare şi de dimensiunile spaţiilor interproximale dentare (4).

Ţesutul cheratinizat din jurul dinţilor este mai rezistent la boala parodontală decât mucoasa alveolară, iar zonele cu mucoasă cheratinizată cu lăţime 
mai mică de $2 \mathrm{~mm}$ pot prezenta semne de inflamaţie. Mai mult de $80 \%$ dintre suprafeţele cu o lăţime gingivală mai mare de $2 \mathrm{~mm}$ nu prezintă aceste semne de îmbolnăvire. În consecinţă, pentru menţinerea sănătăţii gingivale este nevoie de o lăţime de cel puţin $2 \mathrm{~mm}$ de mucoasă cheratinizată (5).

Scopul acestui articol a fost de a evalua statistic morfometric mucoasa orală cheratinizată, cercetările fiind bazate pe determinări clinice.

\section{MATERIAL ŞI METODĂ}

Pentru studiu am efectuat măsurători, cu ajutorul sondei dentare pe care s-a aplicat un stopper de cauciuc, ale înălţimii (lăţimii) mucoasei cheratinizate la nivel incisiv, canin, premolar şi molar, vestibular la maxilar, vestibular şi oral la mandibulă, pe un lot de 31 de pacienţi, 21 de femei şi 10 bărbaţi. Aceşti pacienţi s-au prezentat la un cabinet privat de medicină dentară, în perioada ianuarie 2009 decembrie 2011, pentru diferite tratamente orodentare şi conform consimţântului liber informat au acceptat această determinare. Morfometria nu s-a efectuat palatinal la maxilar pentru că aici nu există o limită de demarcaţie vizibilă între gingie şi mucoasa alveolară. Metodologia este asemănătoare cu cea dintr-un studiu anterior (4).

\section{REZULTATE}

Rezultatele obţinute au fost centralizate şi analizate statistic şi vor fi prezentate în continuare prin grafice.

Vârsta medie a pacienţilor aflaţi în studiu a fost de $28,9 \pm 4,8$ ani la femei, de $27,4 \pm 3,1$ ani la bărbaţi

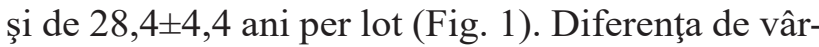
stă între femei şi bărbaţi nu a fost semnificativă din punct de vedere statistic.

Lăţimea (înălţimea) medie a mucoasei cheratinizate la nivel incisiv superior, vestibular, a fost de 4,8 $\pm 0,4$ mm (Fig. 2).

Lăţimea (înălţimea) medie a mucoasei cheratinizate la nivel premolar superior, vestibular, a fost de de 4,7 $\pm 0,4 \mathrm{~mm}$, fiind foarte apropiată dimensional de zona frontală, iar la bărbaţi fiind chiar identică (Fig. 3).

Lăţimea (înălţimea) medie a mucoasei cheratinizate la nivel molar superior, vestibular, a fost de 4,1 $\pm 0,4$ mm, bărbaţii prezentând o lăţime medie mai mare, 4,4 $\pm 0,4 \mathrm{~mm}$, faţă de femei, $4,0 \pm 0,4$ mm (Fig. 4).

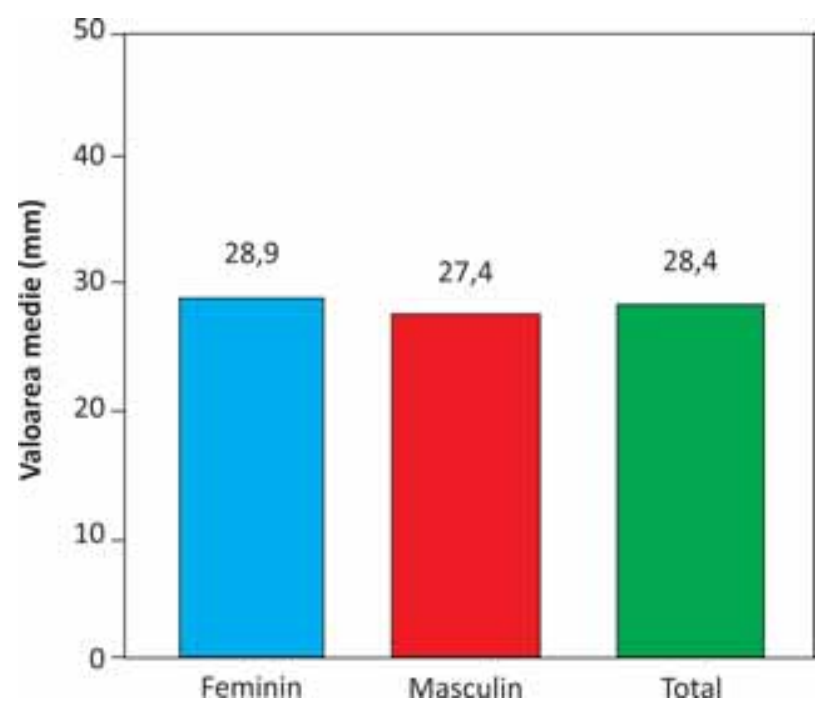

FIGURA 1. Vârsta medie a pacienților în funcție de sex

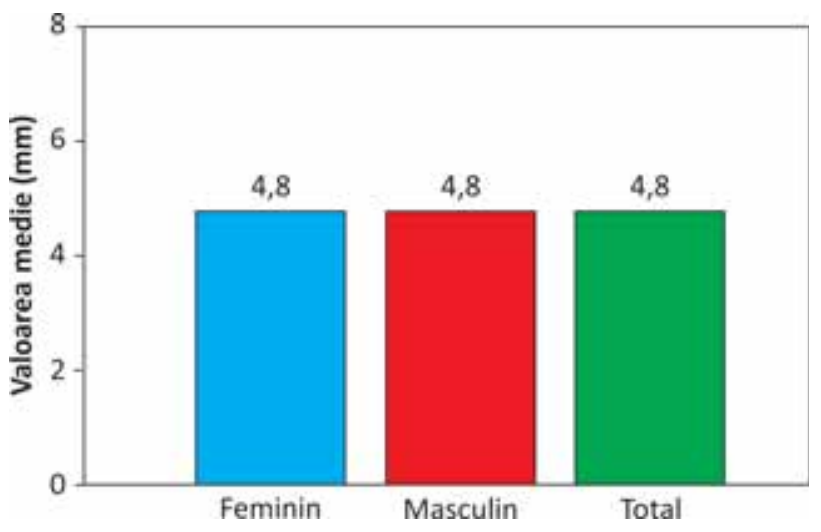

FIGURA 2. Lățimea medie a mucoasei cheratinizate la nivel incisiv superior-vestibular

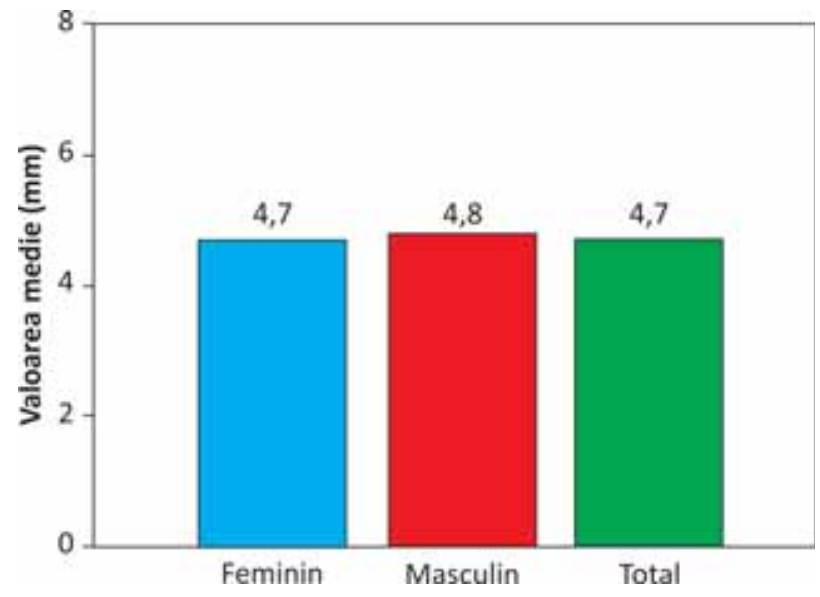

FIGURA 3. Lățimea medie a mucoasei cheratinizate la nivel premolar superior-vestibular

Lăţimea (înălţimea) medie a mucoasei cheratinizate la nivel incisiv inferior, vestibular, a fost de 3,0 $\pm 0,3 \mathrm{~mm}$ (Fig. 5).

Lăţimea (înălţimea) medie a mucoasei cheratinizate la nivel incisiv inferior, lingual, a fost de 2,6 $\pm 0,3 \mathrm{~mm}$ (Fig. 6). 


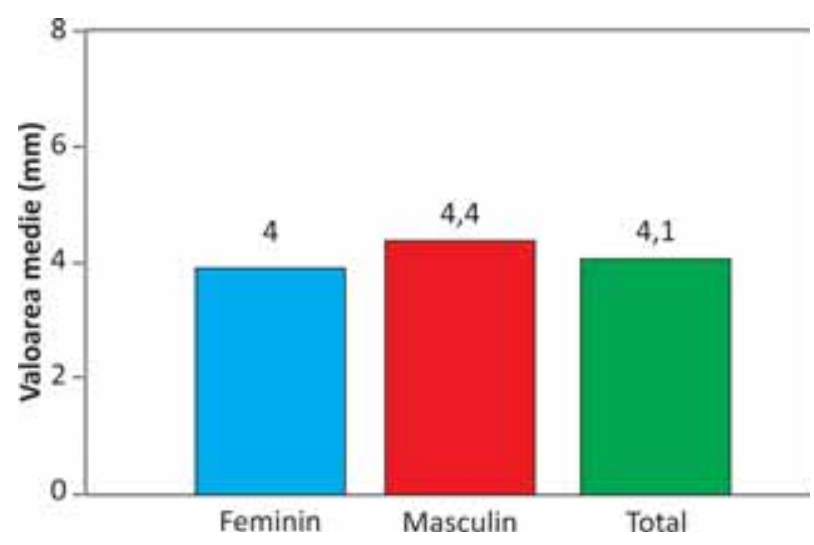

FIGURA 4. Lățimea medie a mucoasei cheratinizate la nivel molar superior-vestibular

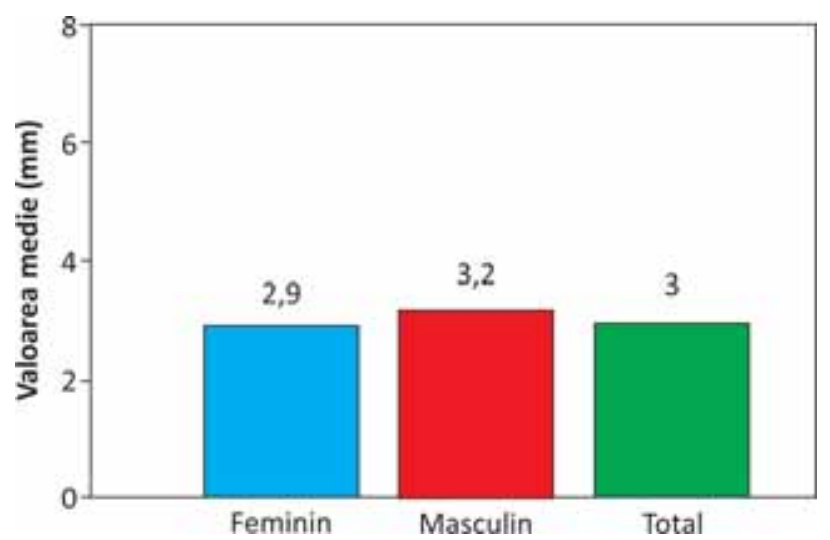

FIGURA 5. Lățimea medie a mucoasei cheratinizate la nivel incisiv inferior-vestibular

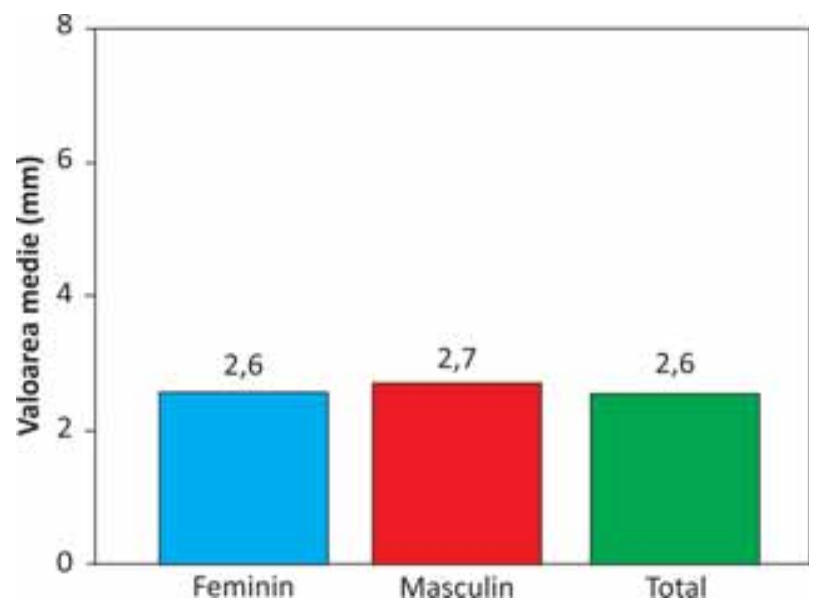

FIGURA 6. Lățimea medie a mucoasei cheratinizate la nivel incisiv inferior - lingual

Lăţimea (înălţimea) medie a mucoasei cheratinizate la nivel premolar inferior, vestibular, a fost de 2,1 $\pm 0,2 \mathrm{~mm}$ (Fig. 7), iar lingual a fost de de 3,3 $\pm 0,3 \mathrm{~mm}$ (Fig. 8).

Lăţimea (înălţimea) medie a mucoasei cheratinizate la nivel molar inferior, vestibular, a fost de $2,3 \pm 0,4 \mathrm{~mm}$ (Fig. 9), iar lingual a fost de de de

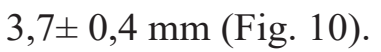

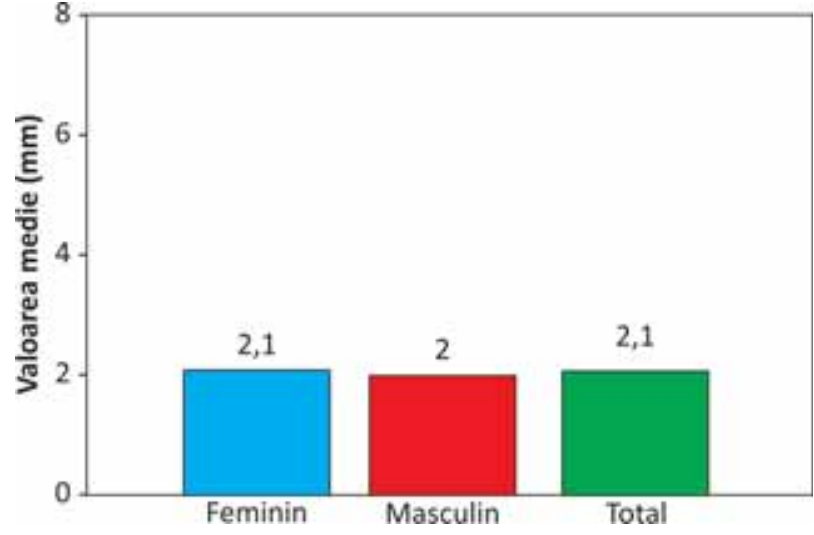

FIGURA 7. Lățimea medie a mucoasei cheratinizate la nivel premolar inferior-vestibular

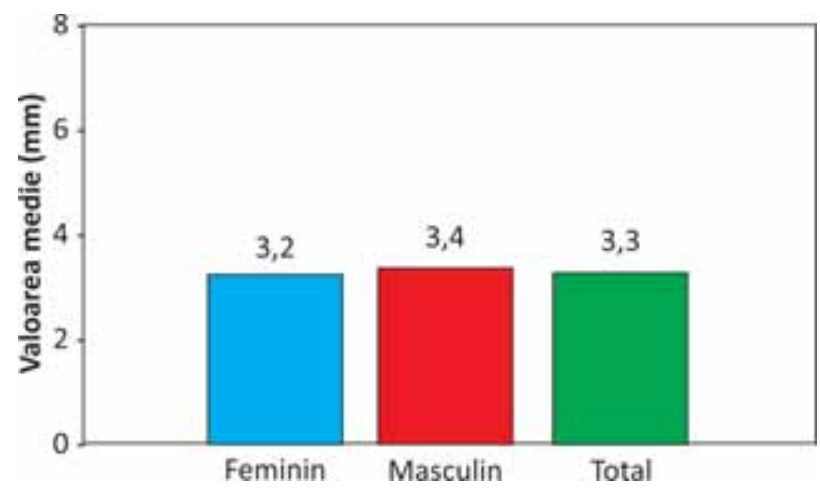

FIGURA 8. Lățimea medie a mucoasei cheratinizate la nivel premolar inferior-lingual

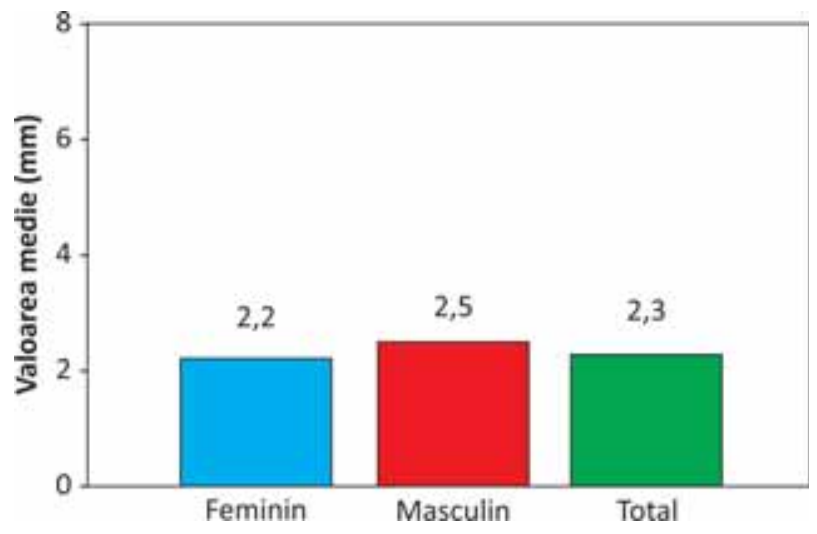

FIGURA 9. Lătimea medie a mucoasei cheratinizate la nivel molar inferior-vestibular

\section{DISCUŢII}

Acest studiu despre morfometria mucoasei cheratinizate efectuat pe populaţie românească arată diferenţe faţă de studii care arată că la maxilar înălţimea cea mai mică este în zona premolară, dar şi asemănări faţă de alte studii de acest gen efectuate pe populaţie europeană, privind înălţimea mucoasei cheratinizate la mandibulă (6). 


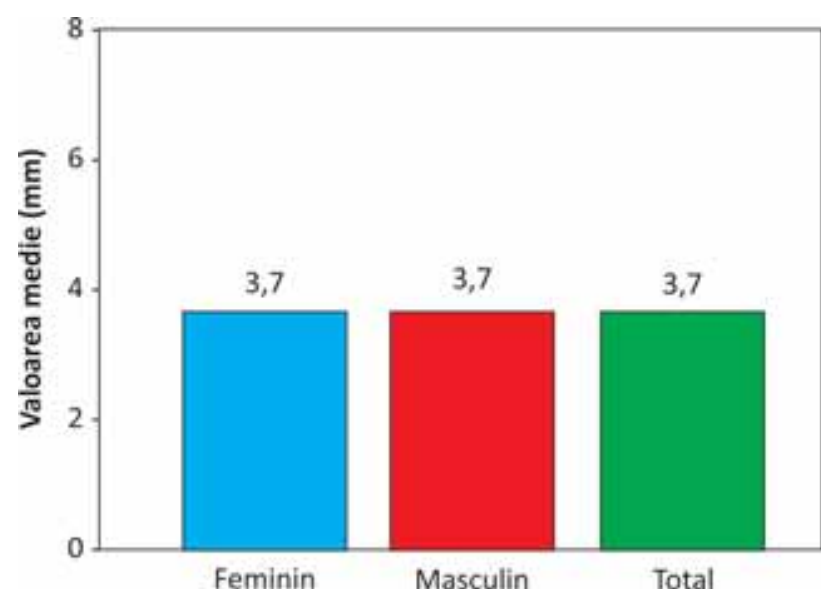

FIGURA 10. Lățimea medie a mucoasei cheratinizate la nivel molar inferior-lingual

De asemenea, am stabilit că există diferenţe între pacienţi şi între diferitele zone maxilo-mandibulare.

O înălţime mai mare a mucoasei keratinizate favorizează stabilitatea marginii gingivale libere, astfel încât o posibilă restaurare protetică să poată fi plasată fără să afecteze sănătatea ţesuturilor moi înconjurătoare $(1,4)$.

Pentru o estetică şi o funcţionalitate superioare, în cazul restaurărilor protetice, este necesară existenţa prealabilă a unor date morfometrice exacte despre mucoasa cheratinizată (7).

Lipsa unei lăţimi adecvate a mucoasei cheratinizate în jurul implanturilor dentare, în special în zonele posterioare ale arcadelor alveolare, a fost asociată cu o mai mare acumulare de placă microbiană şi inflamaţie gingivală consecutivă (8).

O bună estetică a restaurărilor protetice pe implanturi necesită prezenţa ţesutului moale sănătos în zona respectivă. Relevanţa sigiliului de țesut moale în jurul implanturilor dentare, rolul lăţimii mucoasei cheratinizate şi controlul plăcii microbiene pentru a menţine sănătatea ţesuturilor moi peri- implantare trebuie analizate frecvent în practica medicinei dentare (9).

Fluxul sanguin insuficient în ţesuturile moi înconjurătoare şi variaţiile privind vascularizaţia locală pot influenţa negativ vindecarea ţesuturilor moi în jurul implanturilor dentare (10).

Mucoasa cheratinizată favorizează creşterea rezistenţei parodonţiului marginal la injuriile externe şi stabilizează marginea gingivală liberă împotriva agresiunilor mecanice (11).

O lăţime cât mai mare a mucoasei cheratinizate contribuie la diminuarea resorbţiei osoase şi la realizarea unui ataşament stabil de ţesut moale periimplantar (12).

Alţi autori au arătat că înălţimea mucoasei cheratinizate nu este semnificativă pentru menţinerea sănătăţii parodontale în prezenţa unei igiene orale adecvate. $\mathrm{Cu}$ toate acestea, o mucoasă cheratinizată subţire în jurul dinţilor cu restaurări protetice poate fi mai susceptibilă la retracţie. Funcţionalitatea mucoasei cheratinizate din jurul implanturilor dentare nu a fost pe deplin elucidată, dar valoarea sa estetică a fost acceptată pe scară largă (13).

\section{CONCLUZII}

Rolul mucoasei orale cheratinizate în succesul pe termen lung al tratamentului cu implanturi dentare rămâne în continuare, în literatura de specialitate a medicinei dentare, o problemă controversată, pentru că încă nu s-a stabilit un consens în legătură cu interrelaţia dintre înălţimea mucoasei cheratinizate şi sănătatea ţesuturilor moi periimplantare.

\section{RECUNOAŞTERE}

Acest studiu face parte din teza de doctorat a doamnei Asist. Univ. Dr. Simona Andreea Moraru.

\section{BIBLIOGRAFIE}

1. Gaşpar S.A. Studii clinice şi experimentale privind integrarea epitelio-conjunctivă a implanturilor dentare (Clinical and experimental studies on epithelial and connective tissues integration to dental implants). PhD Thesis, "Carol Davila" University of Medicine and Pharmacy, Bucharest, Romania, 2014.

2. Moon I.S., Berglundh T., Abrahamsson I., Linder E., Lindhe J. The barrier between the keratinized mucosa and the dental implant. An experimental study in the dog. $J$ Clin Periodontol 1999; 26(10): 658-63.

3. Ten Cate A.R. Oral Histology: Development, Structure and Function. Ed. 4. Mosby Co, St. Louis, USA, 1994.

4. Moraru S., Nimigean V., Nimigean V.R., Sălăvăstru D.I. The width of the gingiva-Clinical correlations regarding soft tissue integration around dental implants. Ro J Stomatol 2013; 59(1): 28-31.

5. Greenstein G., Cavallaro J. The clinical significance of keratinized gingiva around dental implants. Compend Contin Educ Dent 2011; 32(8): 24-31. 
6. Lindhe J. Clinical Periodontology and Implant Dentistry. Blackwel Munksgaard, lowa-USA, 2005.

7. Myshin L.H., Wiens P.J. Factors affecting soft tissue around dental implants: A review of the literature. J Prosthet Dent 2005; 94(5): 440-4.

8. Chung D.M., Oh T.J., Shotwell J.L., Misch C.E., Wang H.L. Significance of keratinized mucosa in maintenance of dental implants with different surfaces. J Periodontol 2006; 77(8): 1410-20.

9. Yeung S.C. Biological basis for soft tissue management in implant dentistry. Aust Dent J 2008; 53(Suppl 1): 39-42.

10. Nimigean V., Poll A., Nimigean V.R., Moraru S.A., Badita, D.G., Paun D.L. The Routine and Specialised Staining for the
Histologic Evaluation of Autogenous Mandibular Bone Grafts. An experimental study. Rev Chim (Bucharest) 2018; 69(5): 1106- 09.

11. Malthi K., Singh A., Rajula M.P.B., Sabale D. Attached Gingiva: A Review. IJSRR 2013; 3(2): 188-98.

12. Poll A., Nimigean V.R., Bădiţă D., Bălăceanu R.A., Cismas S.C., Perlea P., Moraru S.A., Nimigean V. In vivo experimental model for the evaluation of dental implant integration. Rom Biotech Lett 2018; 23(2): 13505-10.

13. Mehta P., Lim L.P. The width of the attached gingiva-much ado about nothing? J Dent 2010; 38(7): 517-25.

Conflict of interest: none declared Financial support: none declared 